\title{
Environment from a different perspective: Analysing the environmental problem awareness of undergraduates
}

\author{
Sinem Dinçol Özgür ${ }^{1}$, Lütfiye Varoğlu ${ }^{2 *}$, and Ayhan Yılmaz $^{1}$ \\ ${ }^{1}$ Hacettepe University, Beytepe, Ankara, 06800, Turkey \\ ${ }^{2}$ European University of Lefke, Lefke Northern Cyprus TR-10 Mersin, 99728, Turkey
}

\begin{abstract}
The study aims to analyse the awareness levels of university students towards the environmental problems in terms of the variables of faculty and gender. The study was conducted with 149 undergraduate students from the faculty of engineering, health sciences and educational sciences in North Cyprus. The research conducted with survey study and identified the awareness levels of students towards environmental problems through "Environmental Problems Awareness Scale", developed by Güven and Aydoğdu [1] in consideration with the cognitive steps according to the Bloom Taxonomy. In addition to descriptive statistics, $t$ test, ANOVA and MANOVA analyses were used for the analysis of data. The study concluded that the total students' scores for awareness of environmental problems show statistically significant difference based on gender, and no significant difference based on faculties. Additionally, the factor scores of the scale have statistically significant difference based on faculties, and no significant difference based on gender.
\end{abstract}

Keywords: awareness for environmental problems, Bloom's taxonomy, environmental education, environmental problems, university students

\section{Introduction}

The elements such as increasing use of resources in parallel with the increase in population, fast use of natural resources to meet raw material and energy needs, consumption of fossil fuels, industrializing society and increase in the pace of rural depopulation has begun to major problems in terms of environment. Therefore, some ecological and environmental problems such as population increase and problem of settlement, energy problem, agricultural problems, desertification, deforestation, extinction of species and global warming have arisen [2]. Nowadays, environmental problems threaten the whole world [3]. The individuals, who have an impact on the occurrence of environmental problems, can only contribute to the elimination of such problems through an effective environmental education [4, 5]. Vaughan et.al [6] defined the environmental education as a continuous learning process aiming to ensure environmental awareness among individuals and provide knowledge, skills, values, attitude and experience with regard to solve the environmental

* Corresponding author: lvaroglu@eul.edu.tr 
problems. Environmental education aims to make individuals be aware of environmental problems, be sensitive to environmental problems through the acquisition of information regarding such problems and make individual contribute on the solution of environmental problems through the positive attitudes about the environment [7]. Literature emphasizes that the interdisciplinary environmental education should be commenced under the preschool science education programs and should become in various levels of primary, secondary and higher education [8]. The increasing environmental knowledge would change environmental attitudes, and the environmental attitude and environmental knowledge would affect the environmental policies [9]. Environmental problems are not only the issues of individuals but whole mankind; hence primarily the individuals should be aware of environmental problems with regard to their solution. The creation and development of environmental awareness and motivation of all individuals to protect their environment are both important steps in the solution of environmental problems [10]. Consequently, this study aims to analyse the awareness levels of university students for environmental problems in consideration with the cognitive domain process under the Bloom Taxonomy. The cognitive domain taxonomy of Bloom is comprised of six levels that are in a hierarchical structure from simple to complex as the knowledge at the bottom and them comprehension, application, analysis, synthesis and evaluation respectively. Any step is the prerequisite of the successor and in order to gain the behaviour on the one-step ahead, the behaviours of previous levels should be acquired. While knowledge, comprehension and application are considered as the sub-cognitive levels; analysis, synthesis and evaluation are as higher-cognitive levels [11, 12, 13].

In consideration with the literature, the studies conducted on the environment mainly analyse the attitudes of students towards environmental problems [14, 15, 16, 17, 18]. There are a limited number of studies analysing the awareness of various student groups regarding environment and environmental problems [19, 20, 21, 22]. In Northern Cyprus, there are a limited number of studies about environment with respect to the environmental awareness and environmental attitude [23, 24, 25], yet there are not any studies analysing the awareness concerning the environmental problems. This study is important as it would influence the environmental awareness towards environmental problems and potential environmental behaviour, and it would guide the environmental education. Hence, this study works towards assessing the awareness of university students in Northern Cyprus for environmental problems.

\section{Method}

\subsection{Significance and aim of study}

Awareness has an impact on the relation of attitude and behaviour, and higher awareness leads individuals to appropriate attitude and behaviour [26]. Consequently, the determination of awareness of students for environmental problems is vital in an effective environmental education regarding the development of positive attitude and behaviours towards the environment. This study is important as it would influence the environmental awareness towards environmental problems and potential environmental behaviour, and it would guide the environmental education. The aim of this study is to analyse the awareness levels of first-year university students in the Northern Cyprus from health, education and engineering faculties for environmental problems as a global subject. Within the framework of this aim, this study pursued to find answers for the following research problems:

1. What are the awareness levels of students for environmental problems? 
a. What are the total scores for awareness levels for environmental problems and scores for knowledge, comprehension, application, analysis, synthesis and evaluation factors?

b. What is the distribution among the answers of students concerning the knowledge, comprehension, application, analysis, synthesis and evaluation factors?

c. What is the distribution of the total score of the awareness for environmental problems and factors by faculties?

2. Is there a statistically significant difference between students' total score and factor scores of the awareness for environmental problems according to their faculties?

3. Is there a statistically significant difference between students' total score and factor scores of the awareness for environmental problems according to their gender?

\subsection{Research model}

The survey study conducted with 149 undergraduate students from the faculty of engineering, health sciences and educational sciences at 2017-2018 spring semester in North Cyprus. The survey studies are conducted with relatively bigger samples than other researches in order to identify the views of participants about a subject or event, or their characteristics such as interest, skills and attitude [27].

\subsection{Participants}

The study was conducted with 149 undergraduate students from the faculty of engineering, health sciences and educational sciences at a higher education institution in North Cyprus during the spring term of 2017-2018. The ages of students vary between 18 and 27 with an average of 19.97. Table 1 shows the distribution of students with regard to their genders and faculties.

Table 1. Distribution of students with regard to their genders and faculties

\begin{tabular}{lccc}
\hline Faculty & Female & Male & Total \\
\hline Faculty of Health Sciences & 48 & 17 & 65 \\
\hline Faculty of Engineering & 7 & 30 & 37 \\
\hline Faculty of Education & 28 & 19 & 47 \\
\hline Total & 83 & 66 & 149 \\
\hline
\end{tabular}

\subsection{Data collection tool}

The Awareness Scale for Environmental Problems: The Awareness Scale for Environmental Problems developed by Güven and Aydoğdu [1] was used in order to identify the awareness of students towards the environmental problems. The scale is comprised of 44 items rated as "yes", "no" and "no idea" and six factors. In the development of scale and creation of factors, the researchers considered the cognitive levels under the Bloom Taxonomy. The Cronbach Alpha values of scale are calculated as 0.90 for total; 0.95 for knowledge factor; 0.95 for comprehension factor; 0.91 for application factor; 0.90 for analysis factor; 0.75 for synthesis factor and 0.71 for evaluation factor. Under the scale, the answers as "yes" were rated with " 2 " points, "no" with " 0 " points and "no idea" with " 1 points". The highest score that is possible to get from the scale is 88 and 0 as the lowest [1]. 


\section{Data analysis}

In addition to the descriptive statistics, t-test, ANOVA and MANOVA analyses were also used accordingly for data analysis.

\section{Findings and Interpretation}

\subsection{Findings}

The findings generated as a result of this study are presented with respect to the order of research problems. Concerning the first research problem and sub-problems;

1.a. Firstly, in the analysis of awareness levels of students for the environmental problems, the total scores of participant students and their scores from the factors of knowledge, comprehension, analysis, synthesis and evaluation were assessed. The average scores students from the total of scale and factors are given in Table 2.

Table 2. The average scores students from the total of scale and factors

\begin{tabular}{lcccc}
\hline & $\mathbf{N}$ & Minimum & Maximum & Mean \\
\hline Total score & 149 & 49.00 & 77.00 & 66.59 \\
\hline Knowledge & 149 & 7.00 & 16.00 & 11.70 \\
\hline Comprehension & 149 & 7.00 & 15.00 & 11.28 \\
\hline Application & 149 & 4.00 & 12.00 & 9.81 \\
\hline Analysis & 149 & 4.00 & 16.00 & 12.78 \\
\hline Synthesis & 149 & 2.00 & 14.00 & 9.60 \\
\hline Evaluation & 149 & 5.00 & 14.00 & 11.40 \\
\hline
\end{tabular}

1.b. Figure 1 reflects the distribution of answers given by the students regarding the factors of scale, as "yes, no idea and no":

While $74.9 \%$ of students answered the statements under the application level as "yes" with the highest percentage, $19.1 \%$ of them answered as "no" for the statements under the synthesis statement as the highest percentage. Moreover, figure 3 shows that $38.3 \%$ of students answered the statements under the knowledge level as "no idea".

1.c. Table 3 shows the total scores of students obtained from the awareness scale for environmental problems and the distribution of scores with regard to the factors by their faculties.

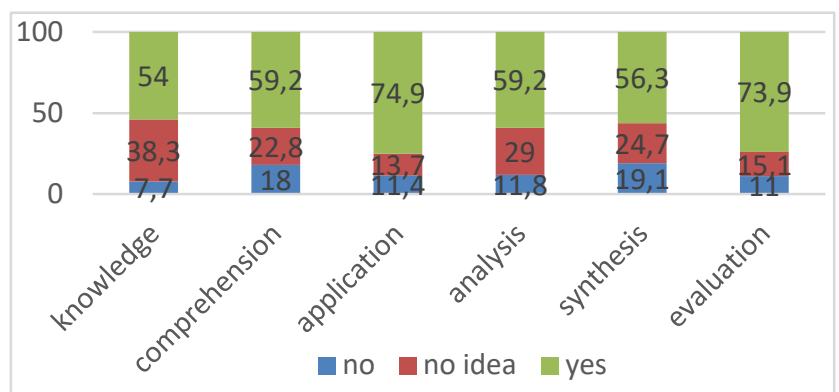

Figure 1. Distribution of answers given by students about factors 
Table 3. Distribution of average scores among students in terms of the total scale and factors

\begin{tabular}{lllrc}
\hline & Faculty & N & Mean & Std. Dev. \\
\hline \multirow{3}{*}{ Total score } & Health Sciences & 65 & 67.50 & 6.00 \\
\cline { 2 - 5 } & Engineering & 37 & 65.91 & 7.19 \\
\cline { 2 - 5 } Knowledge & Education & 47 & 65.87 & 5.61 \\
\hline \multirow{3}{*}{ Health Sciences } & 65 & 12.06 & 2.03 \\
\cline { 2 - 5 } & Engineering & 37 & 11.21 & 1.88 \\
\cline { 2 - 5 } & Education & 47 & 11.59 & 1.81 \\
\hline \multirow{3}{*}{ Application } & Health Sciences & 65 & 11.60 & 1.23 \\
\cline { 2 - 5 } & Engineering & 37 & 11.21 & 1.61 \\
\cline { 2 - 5 } & Education & 47 & 10.91 & 1.57 \\
\hline \multirow{3}{*}{ Analysis } & Health Sciences & 65 & 10.15 & 1.59 \\
\cline { 2 - 5 } & Engineering & 37 & 10.00 & 1.66 \\
\cline { 2 - 5 } & Education & 47 & 9.19 & 1.80 \\
\hline \multirow{3}{*}{ Synthesis } & Health Sciences & 65 & 12.83 & 1.78 \\
\cline { 2 - 5 } & Engineering & 37 & 12.78 & 2.07 \\
\cline { 2 - 5 } & Education & 47 & 12.72 & 1.47 \\
\hline \multirow{3}{*}{ Evaluation } & Health Sciences & 65 & 9.32 & 2.42 \\
\cline { 2 - 5 } & Engineering & 37 & 9.45 & 2.34 \\
\cline { 2 - 5 } & Education & 47 & 10.10 & 2.22 \\
\hline & Health Sciences & 65 & 11.53 & 1.55 \\
\cline { 2 - 5 } & Engineering & 37 & 11.24 & 1.93 \\
\cline { 2 - 5 } & Education & 47 & 1.34 & 2.07 \\
\hline
\end{tabular}

Table 4 delivers the answers concerning the statements selected from each factor in order to analyse the answers of students in terms of factors in detail to the extent of their faculties and genders.

Table 4 indicated that $83.2 \%$ of students answered the item on renewable energy as yes with regard to the knowledge factor. In terms of comprehension factor, $97.3 \%$ of students answered the item about the generalization of environmental education as yes. With respect to analysis factor, the majority of students noted that they acknowledge the existence of environmental problems causing significant global problems and through the item under the evaluation factor; they consider the prevention of such environmental problems with the contribution of all countries. Similarly under the synthesis factor, $72.5 \%$ of students answered the $27^{\text {th }}$ item indicating that environmental problems are global as yes.

The result of single factor ANOVA test conducted for the $2^{\text {nd }}$ research problem noted that the total awareness level scores of students for the environmental problems do not vary based on their faculties $[\mathrm{F}(2,146)=1.24, \mathrm{p}>.05]$. Pursuant to the research problem, the MANOVA results undertaken over the factor scores of knowledge, comprehension, application, analysis, synthesis and evaluation indicated that the students from educational sciences faculty, health sciences faculty and engineering faculty show significant difference in terms of their faculties [Wilks Lambda $(\wedge)=0.829, \mathrm{~F}(12,282)=2,31, \mathrm{p}<.01$ ]. This findings shows that the scores generated from the linear component composed of factor scores differ based on the faculties of students. Therefore, the comprehension and application scores of scale show significant difference by faculty $[\mathrm{F}(2,146)=3.12, \mathrm{P}<.05$; $\mathrm{F}(2,146)=4.78, \mathrm{P}<.05]$, there is not any significant difference between the factor scores of knowledge, analysis, synthesis and evaluation. While the students from faculty of health sciences have the highest scores from comprehension and application, the students from Engineering and Educational Sciences follow up respectively (Table 3). 


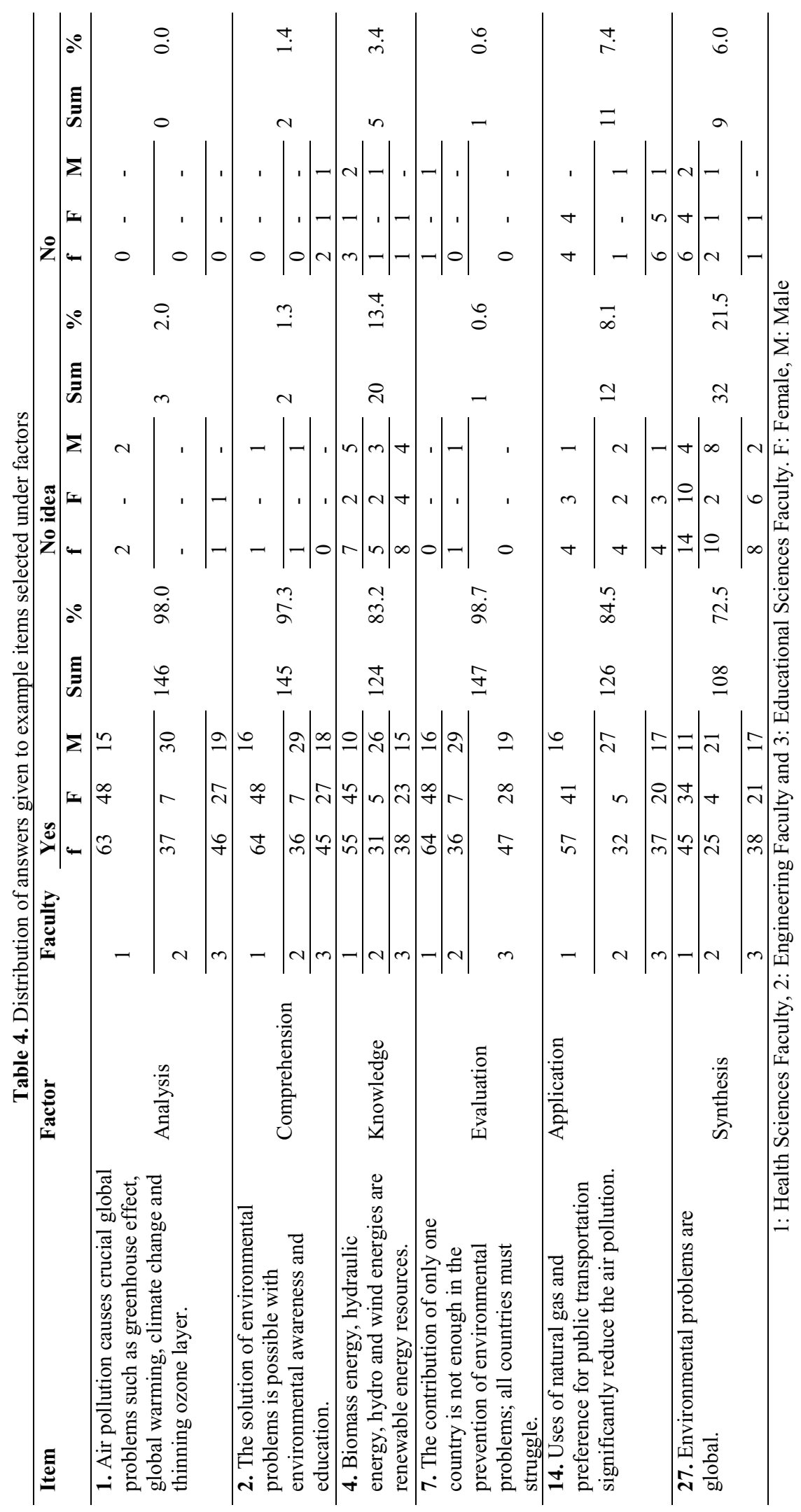


The result of independent sample t-test conducted regarding the $3^{\text {rd }}$ research problem reflected that the total awareness scores of students for the environmental problems show significant difference by their gender $\mathrm{t}(147)=2.35, \mathrm{p}=.02, \mathrm{p}<.05$. The total awareness scores of female students for the environmental problems are $(\bar{X}=67.65)$ are higher than male students $(\bar{X}=65.27)$. Table 5 gives the average factor scores for female and male students.

Table 5. Average factor scores for female and male students

\begin{tabular}{lcccccc}
\hline & \multicolumn{7}{c}{ Average Scores } \\
\cline { 2 - 7 } & Knowledge & Comprehension & Application & Analysis & Synthesis & Evaluation \\
\hline Female & 12.04 & 11.40 & 9.72 & 13.00 & 9.82 & 11.68 \\
\hline Male & 11.28 & 11.15 & 9.92 & 12.51 & 9.33 & 11.06 \\
\hline
\end{tabular}

Table 5 indicated that the averages of knowledge, comprehension, analysis, synthesis and evaluation factors are high in favour of female students whereas the average score of application factor is even a little high in favour of male students. Considering the result of MANOVA test, which was conducted in order to analyse whether scores for the factors of knowledge, comprehension, analysis, synthesis and evaluation vary based on the genders of student, the factor scores of students do not show any difference based on their gender [Wilks Lambda $(\wedge)=0.917, \mathrm{~F}(6,142)=2.13, \mathrm{p}=.052 \mathrm{p}>.05$ ].

\subsection{Conclusion and Discussion}

This study was performed to analyse the awareness levels of undergraduates from various faculties of a university located in the Northern Cyprus for environmental problems, and to assess in terms of variables as faculties and gender. In consideration of descriptive analyses, the average awareness scores of students for environmental problems were found as $\bar{X}=66.59$ and distributed between 49 and 77. Pursuant to the highest score (88) that is possible to get from the scale, the students have a certain awareness level. With regard to the answers given for the factors under the awareness scale for environmental problems, the students mainly answered as yes for all levels. While $74.9 \%$ of students gave the answer of yes to the application level with the highest rate; the lowest rate for the answer of yes and the highest rate for the answer of no idea were given to knowledge level with $54.0 \%$ and $38.3 \%$ respectively. Such rates indicate that the students have insufficient knowledge with regard to the environmental problems. On the other hand, pursuant to the rates for the answer of yes towards the scale items under Table 4, the students are considered as aware that the environmental problems are global issues of all countries around the world $(98.7 \%)$ and they believe that environmental education should become more general (97.3\%) for the solution of such problems. However, considering that the awareness levels of individuals for the environmental problems would support the positive attitude and behaviours on the environment, the awareness of university students was found as below the desired level. Özdemir et.al. [28] noted that the awareness and sensitivity levels of medical school students are insufficient. In parallel with the study outcome and literature, the awareness levels of individuals for the environment and environmental problems were referred as insufficient [29, 30, 31, 32].

Pursuant to the awareness score averages of students for the environmental problems in terms of their faculties, the students of health sciences faculty have higher awareness scores when compared with the students from engineering and educational sciences faculty. As the field of students from the health sciences faculty is health itself, and considering the relation between health and environmental problems, such higher awareness levels among these students might be expected. Ek et.al. [33] noted that the attitude and sensitivity of students regarding the environmental problems vary based on their on-going academic 
program. The studies of Köse et.al [34] stated that the environmental attitudes of students from the health sciences faculty are higher than the students from the faculties of engineering and economic and administrative sciences. Yıldırım et.al [35] concluded that although the students of health sciences faculty have more environmental knowledge than the students from other programs, their environmental behaviours do not differ. According to the study of Tekin and Güneş [36] regarding the environmental awareness of first and fourth grade students from various faculties, the education level of parents and hobbies have an impact on the environmental behaviours; and the students from the dentistry faculty have lower level of attitudes although the students from the engineering faculty have higher pro-environmental attitude than the students from the faculty of economics and administrative sciences.

The total awareness scores of students for the environmental problems were found as in favour of female students, yet the factor scores do not show any significant difference by gender. Biswas [37] noted that the environmental awareness of female students is higher than male students and Blocker and Eckberg [38] stated that in relation with the gender identity, the male individuals are in the role of breadwinner and the environmental attitude differ with the gender factor. Moreover, depending on higher awareness levels of female students than the male students with regard to the individual responsibility and environmental problems, the female students have also higher environmental attitudes [39]. The study of Doğan and Purutçuoğlu [20] concluded in their study that the general awareness scores of social service officers do not vary with their genders but in terms of comprehension dimension, women are more aware of environmental problems and more successful in comprehending its reasons. Pursuant to various researches, the female students have higher environmental awareness than male students; bear more environmental concern and are more sensitive in taking measures for the protection of environment $[28,40]$.

Nowadays, as the environmental problems have the tendency to increase, the most effective way to minimize such problems would be the education of individuals and development of environmental awareness, consciousness and attitude. Education is a long process starting from pre-school to university and further on. As the university students of today would have the duty to raise the future generations, all undergraduate programs should be comprised of effective environmental education curricula aiming to raise conscious and sensitive graduates with higher awareness level. One of the restrictions of this study is that the awareness level for the environmental problems are not associated with the courses of students with regard to the environment. It is recommended to ascertain this relation in the future studies.

\section{References}

1. Güven, E., \& Aydoğdu, M. (2012). Çevre sorunlarına yönelik farkındalık ölçeğinin geliştirilmesi ve öğretmen adaylarının farkındalık düzeylerinin belirlenmesi. Öğretmen Ĕ̆itimi ve Ĕ̆itimcileri Dergisi, 1(2), 185-202.

2. Türkmen, L. (2017). Ekolojik konu ve sorunlar. O. Bozkurt (Ed.), Çevre eğitimi (153178). Ankara: Pegem Akademi.

3. Oweini, A., \& Houri, A. (2006). Factors affecting environmental knowledge and attitudes among Lebanese college students. Applied Environmental Education and Communication, 5(2), 95-105.

4. Ünal, S., \& Dimışlı, E. (1999). UNESCO-UNEP himayesinde çevre eğitiminin gelişimi ve Türkiye'de ortaöğretim çevre eğitimi. Hacettepe Üniversitesi Ĕ̆itim Fakültesi Dergisi, 17(17), 142-154. 
5. Şahin, N. F., Cerrah, L., Arzu, S. A. K. A., \& Şahin, B. (2014). Yüksek öğretimde öğrenci merkezli çevre eğitimi dersine yönelik bir uygulama. Gazi Üniversitesi Gazi Eğitim Fakültesi Dergisi, 24(3), 113-128.

6. Vaughan, C., Gack, J., Solorazano, H., \& Ray, R. (2003). The effect on environmental education on schoolchildren, their parents, and community members: a study of intergenerational and intercommunity learning. The Journal of Environmental Education, 34(3), 12-21.

7. İleri, R. (1998). Çevre eğitimi ve katılımın sağlanması. Ekoloji Çevre Dergisi, 7(28), 3-9.

8. Yılmaz, A., Morgil, F. İ., Aktuğ, P., \& Göbekli, İ. (2002). Ortaöğretim ve üniversite öğrencilerinin çevre, çevra kavramları, ve sorunları konusundaki bilgileri ve öneriler. Hacettepe Üniversitesi Ĕ̆itim Fakültesi Dergisi, 22(22), 156-162.

9. Arcury, T. (1990). Environmental attitude and environmental knowledge. Human organization, 49(4), 300-304.

10. Jinliang, W., Yunyan, H., Ya, L., Xiang, H., Xiafel, W., \& Yuanmei, J. (2004). An analysis of environmental awareness and environmental education for primary school and high school students in Kunming. Chinese Education \& Society, 37(4), 24-31.

11. Bloom, B. S. (1956). Taxonomy of educational objectives. Vol. 1: Cognitive domain. New York: McKay, 20-24.

12. Krathwohl, D. R. (2002). A revision of Bloom's taxonomy: An overview. Theory into practice, 41(4), 212-218.

13. Köğce, D., Aydın, M., \& Yıldız, C. (2009). Bloom taksonomisinin revizyonu: Genel bir bakış. İlkögretim Online, 8(3), 1-7.

14. Aksu, Y., \& Erduran Avc1, D. (2009). Fen ve teknoloji ile sınıf öğretmenlerinin çevre sorunlarına yönelik tutum ve görüşlerinin belirlenmesi: Burdur ili örneği. Sakarya Üniversitesi Ĕ̌itim Fakültesi Dergisi, 17, 59-80.

15. Bradley, J. C., Waliczek, T. M., \& Zajicek, J. M. (1999). Relationship between environmental knowledge and environmental attitude of high school students. The Journal of Environmental Education, 30(3), 17-21.

16. Hacıeminoğlu, E., Alp, E., \& Ertepınar, H. (2006). Öğretmen adaylarının çevreye ve çevre konularını öğretmeye yönelik tutumları. VII. Ulusal Fen Bilimleri ve Matematik Eğitimi Kongresi Ö̈zetler Kitabı, 07-09.

17. Özmen, D., Çetinkaya, A. Ç., \& Nehir, S. (2005). Üniversite öğrencilerinin çevre sorunlarına yönelik tutumları. TSK Koruyucu Hekimlik Bülteni, 4(6), 330-344.

18. Worsley, A., \& Skrzypiec, G. (1998). Environmental attitudes of senior secondary school students in South Australia. Global Environmental Change, 8(3), 209-225.

19. Coertjens, L., Boeve-de Pauw, J., De Maeyer, S., \& Van Petegem, P. (2010). Do schools make a difference in their students'environmental attitudes and awareness? Evidence from pisa 2006. International Journal of Science and Mathematics Education, 8(3), 497-522.

20. Doğan, İ., \& Purutçuoğlu, E. (2017). Sosyal hizmet uzmanlarının çevresel farkındalık seviyeleri ile çevreye yönelik tutumlarının belirlenmesi. Türkiye Sosyal Araştırmalar Dergisi, 2, 389-405.

21. Korhonen, K., \& Lappalainen, A. (2004). Examining the environmental awareness of children and adolescents in the Ranomafana region, Madagascar. Environmental Education Research, 10(2), 195-216.

22. Özdemir, A., \& Yapıcı, E. (2010). Öğretmen adaylarının çevre sorunlarına yönelik farkındalık ve ilgi düzeylerinin karşılaştırılması. Anadolu Doğa Bilimleri Dergisi, 1(1), 48-56.

23. Akış, S. (2000). Kuzey Kıbrıs' ta çevre bilinci. Doğuş Ünivesitesi Dergisi, 1 (1), 7-17.

24. Özdemir, E. B., Kaşot, N. (2015). Fen Eğitimi ve Araştırmaları Derneği Fen Bilimleri Ögretimi Dergisi, 3(1), 16-39. 
25. Varoğlu, L., Temel, S., \& Yilmaz, A. (2018). Knowledge, attitudes and behaviours towards the environmental issues: Case of Northern Cyprus. EURASIA Journal of Mathematics, Science and Technology Education, 14(3), 997-1004.

26. Hutton, D. G., \& Baumeister, R. F. (1992). Self-awareness and attitude change: Seeing oneself on the central route to persuasion. Personality and Social Psychology Bulletin, 18(1), 68-75.

27. Fraenkel, J. R., Wallen, N. E., \& Hyun, H. H. (1993). How to design and evaluate research in education (Vol. 7). New York: McGraw-Hill.

28. Özdemir, O., Yıldız, A., Ocaktan, E., Sarışen, Ö. (2004). Tıp fakültesi öğrencilerinin çevre sorunları konusundaki farkındalık ve duyarlılıkları. Ankara Üniversitesi Tıp Fakültesi Mecmuasi, 57(03), 117-127.

29. Aminrad, Z., Zakaria, S. Z. \& Hadi, A. S. (2011). Influence of age and level of education on environmental awareness and attitude: case study on Iranian students in Malaysian universities. Medwell Journals, 6(1), 15-19.

30. Demirbaş, M., \& Pektaş, H. M. (2009). İlköğretim öğrencilerinin çevre sorunu ile ilişkili temel kavramları gerçekleştirme düzeyleri. Necatibey Eğitim Fakültesi Elektronik Fen ve Matematik Ĕgitimi Dergisi, 3(2), 195-211.

31. Hassan, A., Noordin, T. A. \& Sulaiman, S. (2010). The status of the level of environmental awareness in the concept of sustainable development amongst secondary school students. Procedia - Social and Behavioral Sciences, 2(2), 1276-1280.

32. Oğuz, D., Çakcı, I., \& Kavas, S. (2011). Yüksek öğretimde öğrencilerin çevre bilinci. Turkish Journal of Forestry, 12(1), 34-39.

33. Ek, H. N., Kilic, N., Ogdum, P., Duzgun, G., \& Seker, S. (2009). 1st and 4 th grade students who are taught in different areas at Adnan Menderes University attitudes toward environment problems and sensitiveness to environmental issues. Kastamonu Journal of Education, 17(1), 125-136.

34. Köse, S., Gencer, A. S., Gezer, K., Erol, G. H., \& Bilen, K. (2011). Investigation of undergraduate students' environmental attitudes. International Electronic Journal of environmental education, 1(2), 85-96.

35. Yıldırım, F., Yücel Işııldar, G. A., Erkoç, F., Onat, P., \& Nazan Alparslan, Z. (2015). Examining impacts of natural sciences education in comparison with health and social sciences for pro-environmental behaviours in Turkey. Journal of Integrative Environmental Sciences, 12(3), 189-204.

36. Tekin, C., \& Gunes, G. (2018). Environmental awareness in university students and the affecting factors. International Journal Of Community Medicine And Public Health, 5(2), 422-429.

37. Biswas, M. M. (2017). A study on the environmental awareness of secondary school students in relation to gender, locale of study and medium of instruction. International Education and Research Journal, 3(12), 86-88.

38. Blocker, T. J., \& Eckberg, D. L. (1997). Gender and environmentalism: Results from the 1993 general social survey. Social Science Quarterly, 78(4), 841-858.

39. Tuncer, G., Ertepinar, H., Tekkaya, C., \& Sungur, S. (2005). Environmental attitudes of young people in Turkey: Effects of school type and gender. Environmental Education Research, 11(2), 215-233.

40. Straughan, R. D., \& Roberts, J. A. (1999). Environmental segmentation alternatives: a look at green consumer behavior in the new millennium. Journal of consumer marketing, 16(6), 558-575. 